\title{
STRUCTURAL FEATURES OF FLOWER TRICHOMES IN DRUG EYEBRIGHT (Euphrasia stricta D. Wolff EX J. F. Lehm.)
}

\author{
Weronika Haratym, Elżbieta Weryszko-Chmielewska
}

\author{
Department of Botany, University of Life Sciences in Lublin, Akademicka 15, 20-950 Lublin, Poland \\ e-mail:weronikaharatym@gmail.com
}

Received: 10.06.2013

\begin{abstract}
Euphrasia stricta D. Wolff ex J. F. Lehm. (Orobanchaceae) is a representative of plants that are widely used in folk medicine, phytomedicine, and homeopathy. The medicinal raw material derived from the drug eyebright is applied primarily in treatment of ophthalmic diseases.

The investigations of trichomes in drug eyebright (Euphrasia stricta D. Wolff ex J. F. Lehm) were conducted in 2010-2011. Using light microscopy and scanning electron microscopy, their location and morphological and anatomical features were identified. Three types of non-glandular trichomes were found: short unicellular, long 1-2 celled, and long 2-celled with wall ornamentation. Additionally, 7 types of glandular trichomes were found; these included: unicellular clavate, 2-3-celled clavate, capitate with a unicellular head and a 3-celled stalk, capitate with a unicellular head and a 2-celled stalk, capitate with a 2-celled head, conical papillae, and ribbon-like trichomes with wall thickening.
\end{abstract}

Key words: Euphrasia stricta, flower, glandular trichomes, non-glandular trichomes, location, micromorphology, LM, SEM

\section{INTRODUCTION}

Until recently, the drug eyebright Euphrasia L. has been classified as a representative of the family Scrophulariaceae $[1,2]$. In the new taxonomic system presented on the Angiosperm Phylogeny Website, the genus belongs to the family Orobanchaceae, i.e. one of the clades in the order Lamiales. The genus comprises 350 species. In the Polish flora, only 10 Euphrasia species occur in natural localities [2,3,4,5]. Due to the specific biology, emergence of seasonal races, and easy hybridisation, the genus Euphrasia poses difficulty to plant systematics [6]. In recent years, many species from the genus Euphrasia have been reported to be threatened with extinction. Despite flowering and seed set, its population abundance has been declining from year to year. In Poland, taxonomic and phytogeographical investigations of the drug eyebright were initiated again in 2001 primarily in the south of the country, since data obtained several decades ago proved outdated, given the current state of the art $[7,8,9]$.

Species from the genus Euphrasia are perennial or annual plants with a semi-parasitic life style. Although they are capable of independent life, they achieve a higher growth rate while producing haustoria penetrating the root systems of other plants, in particular representatives of the Fabaceae family [10,11]. Moreover, drug eyebright individuals have been reported to parasitize one another with dominance of some specimens over others [10]. Drug eyebright plants usually reach a height of $30 \mathrm{~cm}$. They have an erect, highly branched stem and ovate or elliptic toothed leaves with an opposite arrangement on the stem. Flowers are borne on the apical parts of shoots between July and September. They are small (ca. $10 \mathrm{~mm}$ ), white or light purple with dark purple stripes and a yellow spot on the lower lip. The fruit is a capsule [12,13]. Investigations of the flowering and pollination biology in E. willkommii have demonstrated that the plant species is relatively seldom visited by pollinators. As assumed by Rawski (1948), this is related to the moderate nectar secretion and poor pollen reward, which is hardly attractive to insects. Additionally, the small-sized tube-shaped flowers emerging too close to the ground prevent the process of pollination by larger insects. Species that were reported to be carrying pollen were ants (Hymenoptera) and thrips (Thysanoptera). A common phenomenon observed in the plant species is self-pollination. At the final stage of flower's life, the corolla elongates, which makes adnate anthers change their position. At the same time, the style does not change its length. In consequence, anthers approach the stigma, which facilitates pollination $[14,15]$. 
Plants of the Euphrasia L. genus are widely known in folk medicine, phytomedicine, and homeopathy as anti-inflammatory, hypotensive, and regenerative agents. Aqueous tinctures or alcohol extracts from the above-ground parts of the eyebright are used for treatment of various eye problems such as cataract, glaucoma, conjunctivitis, red, inflamed, irritated, and sore eyes, corneal ulceration, sharp pain in the eyes, or spastic photophobia. Furthermore, they are recommended for people who suffer from stomach disorders, jaundice, headache, and diseases of the upper respiratory tract $[16,17,18,19]$.

Although there is a lot of information about the medicinal properties of the eyebright, no specific data about the epidermal structures on the flower can be found. The aim of the present study was to examine the location, and micromorphological and anatomical features of non-glandular and glandular trichomes on the surface of the calyx, corolla and anthers of Euphrasia stricta.

\section{MATERIALS AND METHODS}

The research material comprised buds and developed flowers of Euphrasia stricta D. Wolff ex J.F. Lehm. Plant fragments were sampled from their natural habitats on xerothermic grasslands in the Czechów district, Lublin, between late July and mid-September 2010 and 2011.

Preliminary analyses of the ecological features of flowers and location of various types of trichomes were performed using a stereoscopic microscope coupled with a NIKON COOLPIX 4500 camera.

Hand-made cross sections through sepals and corollas were fixed in $50 \%$ glycerol and observed under a Nikon Eclipse 400 light microscope. The types and topography of trichomes were identified. Additionally, their morphological and anatomical traits were assessed and the length and width of the structures were measured.

To obtain permanent preparations, flower fragments were fixed in a $4 \%$ glutaraldehyde solution in $0,1 \mathrm{M}$ phosphate buffer, $\mathrm{pH} 7$, at a temperature of $4 \mathrm{~s}_{\mathrm{C}}$ for 12 hours. Next, the material was washed in the same buffer 4 times at 20-minute intervals, fixed in a $1 \%$ solution of osmium tetroxide for 1 hour, and rinsed again in phosphate buffer. The preparations were dehydrated in 30, 50,70, 90, and 95\% alcohol series and immersed twice in absolute alcohol. After dehydration, the material was embedded in LR White resin and semi-thin sections were cut using a Reichert Ultracut-S ultramicrotome. The preparations were stained with a $1 \%$ aqueous methylene blue - Azur B solution and observed under a light microscope.

Some material was critical-point dried after dehydration. Next, the preparations were coated with gold and analysed under a TESCAN VEGA II LMU scanning electron microscope.

\section{RESULTS}

\section{General habit of the flower}

The flower habit was observed under a stereoscopic light microscope. The hermaphrodite zygomorphic flowers are borne on apical parts of shoots and arranged at an acute angle thereto. At the base, they are surrounded by bristle-toothed bracts (Fig. 1a).

The dark green cylindrical calyx is gamosepalous with four sharp teeth. Its surface bears dark purple stripes (Fig. 1b). The flower corolla is bilabiate (Fig. 1a,c). The lower lip is formed of 3 fused petals. The surface of marginal lobes bears 2 dark purple stripes and 1 light purple medial stripe. The central lobe has 3 light purple stripes as well. A yellow spot is visible in the central part of the middle corolla petal. The entry to the flower throat is also marked with yellow colouration (Fig. 1c).

The upper lip consists of 2 fused corolla petals. It is white initially and becomes light violet during development. Each lobe of the upper lip bears dark purple stripes -3 on each lobe and 1 light purple stripe along the petal fusion line. Yellow colouration is visible at the entry to the corolla tube (Fig.1c,d).

The four stamens with filaments of unequal length are didynamous and fused with the upper lip. The dark purple stamen heads are fused. Anthers are equipped with sharp-tipped appendages in the basal part. The filaments are white with yellow colouration only at the entry to the corolla tube. Their surface bears long mechanical trichomes (Fig. 1d). The pistil has a small green ovary, a long style, and a stigma, which emerges from the flower throat above the stamens and is covered by dense hairs (Fig. 1e).

\section{Corolla trichomes}

The petals bear only one type of non-glandular trichomes and a few types of glandular trichomes. 2-celled mechanical trichomes exhibit the highest density on the abaxial surface of the upper lip (Table 1). On average, they are $346,43 \mu \mathrm{m}$ long and $17,97 \mu \mathrm{m}$ wide (Table 2). Two types of clavate trichomes are located near the yellow spot on the lower lip. These hairs are fairly large and visible under a stereoscopic microscope (Fig. 1f). One of the types is represented by multicellular trichomes with a thin cell wall and visible chromoplasts inside the cells. They reach a length up to 262,5 $\mu \mathrm{m}$ and a width of $40 \mu \mathrm{m}$ (Figs 1g,2g). Close to these hairs, there are unicellular clavate trichomes, which are longer (up to $343,4 \mu \mathrm{m}$ ) than the multicellular ones. Their cell wall is covered by a cuticle, whose sculpture consists of short striae (Figs $1 \mathrm{~h} ; 2 \mathrm{~g}-\mathrm{i}$ ). Remains of secretion were observed on some trichomes (Fig. 2i).

The adaxial surface of the lower and upper lips is covered by densely distributed conical papillae (Figs 1i,j; 2d-f). Their maximum length reaches $15 \mu \mathrm{m}$. The wall of the papillae is covered with apically conver- 
gent striae (Fig. 2e,f). Observation under the scanning electron microscope revealed bulging of the apical part of the papillae, suggesting accumulation of secretion (Fig. 2f).

Three types of capitate trichomes were found on corolla petals. Short trichomes with a 2-celled head, characteristic for eyebright leaves, occurred least frequently. Trichomes with a unicellular head and a 2or 3-celled stalk were considerably more numerous. Their cytoplasm contained chloroplasts, and they had a smooth surface (Figs 1k, 2a-c).

Another type of trichomes was observed in the upper part of the adaxial surface of the upper lip. These were long, twisted, white, multicellular structures with irregular thickenings. Such trichomes are the longest of all the other flower hairs $(411,58 \mu \mathrm{m})$ (Fig. 3a,b). Their entire surface has a characteristic sculpture formed by wrinkled striae (Fig. 3g). This type of trichomes also occurs on anthers, particularly at the dehiscence slit, through which pollen is released (Figs 1d,e; 3a-g).

\section{Calyx trichomes}

No trichomes are borne by the adaxial surface of the calyx. Unicellular, hook-shaped non-glandular trichomes are located on the abaxial surface. Their length ranges from 30,0 to $82,5 \mu \mathrm{m}$ (mean $48,86 \mu \mathrm{m}$ ). They are characterised by a striated cuticle (Fig. 2a,b). 1-2-celled trichomes have a mean length of $96,5 \mu \mathrm{m}$. Among the mechanical trichomes, three types of glandular trichomes are located: the most common capitate hairs with a 2-celled head, single capitate trichomes with a unicellular head and a 2-celled stalk, and capitate trichomes with a unicellular head and a 3-celled stalk. The sizes of the trichomes are presented in Table 2.

Table 1

Distribution of different types of flower trichomes in Euphrasia stricta

\begin{tabular}{|c|c|c|c|c|c|c|c|}
\hline \multirow{3}{*}{ Types of trichomes } & \multicolumn{2}{|c|}{ Calix } & \multicolumn{4}{|c|}{ Corolla } & \multirow{3}{*}{ Stamen } \\
\hline & \multirow{2}{*}{$\begin{array}{l}\text { Adaxial } \\
\text { surface }\end{array}$} & \multirow{2}{*}{$\begin{array}{l}\text { Abaxial } \\
\text { surface }\end{array}$} & \multicolumn{2}{|c|}{ Lower lip } & \multicolumn{2}{|c|}{ Upper lip } & \\
\hline & & & $\begin{array}{c}\text { Abaxial } \\
\text { surface }\end{array}$ & $\begin{array}{c}\text { Adaxial } \\
\text { surface }\end{array}$ & $\begin{array}{l}\text { Abaxial } \\
\text { surface }\end{array}$ & $\begin{array}{c}\text { Adaxial } \\
\text { surface }\end{array}$ & \\
\hline \multicolumn{8}{|c|}{ Non - glandular } \\
\hline Short unicellular & - & +++ & - & - & - & - & \\
\hline Long $1-2$ celled & - & ++ & - & - & - & - & \\
\hline Long 2-celled with wall ornamentation & - & - & +++ & - & +++ & ++ & ++ \\
\hline \multicolumn{8}{|c|}{ Glandular } \\
\hline 2-3-celled clavate & - & - & - & +++ & - & - & \\
\hline Unicellular clavate & - & - & - & +++ & - & - & \\
\hline Capitate with a unicellular head and a 2-celled stalk & - & + & - & - & +++ & ++ & \\
\hline Capitate with a unicellular head and a 3-celled stalk & - & + & - & - & +++ & ++ & \\
\hline Capitate with a 2-celled head & - & +++ & - & + & - & + & \\
\hline Papillae & - & - & - & +++ & - & +++ & \\
\hline Ribbon-like trichomes with wall thickening & - & - & - & - & - & ++ & +++ \\
\hline
\end{tabular}

Table 2

Dimensions of flower trichomes in Euphrasia stricta

\begin{tabular}{|c|c|c|c|c|c|c|}
\hline \multirow{2}{*}{ Types of trichomes } & \multicolumn{3}{|c|}{ Length $[\mu \mathrm{m}]$} & \multicolumn{3}{|c|}{ Width $[\mu \mathrm{m}]$} \\
\hline & Min. & Max. & Mean & Min. & Max. & Mean \\
\hline \multicolumn{7}{|c|}{ Non - glandular } \\
\hline Short unicellular & 30,0 & 82,5 & 48,86 & 25,0 & 45,0 & 34,25 \\
\hline Long $1-2$ celled & 62,5 & 162,5 & 96,50 & 15,0 & 35,0 & 27,13 \\
\hline Long 2-celled with wall ornamentation & 202,0 & 535,3 & $\mathbf{3 4 6 , 4 3}$ & 12,5 & 27,5 & 17,97 \\
\hline \multicolumn{7}{|c|}{ Glandular } \\
\hline 2-3-celled clavate & 180,0 & 262,5 & 219,25 & 15,0 & 30,0 & 20,75 \\
\hline Unicellular clavate & 202,0 & 343,4 & 266,39 & 25,0 & 4,0 & 32,38 \\
\hline Capitate with a unicellular head and a 2-celled stalk & 42,5 & 62,5 & 53,70 & 26,3 & 30,0 & 28,75 \\
\hline Capitate with a unicellular head and a 3-celled stalk & 72,5 & 100,0 & 83,30 & 27,5 & 35,0 & 31,25 \\
\hline Capitate with a 2-celled head & 32,5 & 65.0 & 45,50 & 30,0 & 45,0 & 36,25 \\
\hline Papillae & 12,5 & 15,0 & 13,36 & 10,0 & 17,5 & 13,63 \\
\hline Ribbon-like trichomes with wall thickening & 171,7 & 676,7 & 411,58 & 10,0 & 30,0 & 20,19 \\
\hline
\end{tabular}



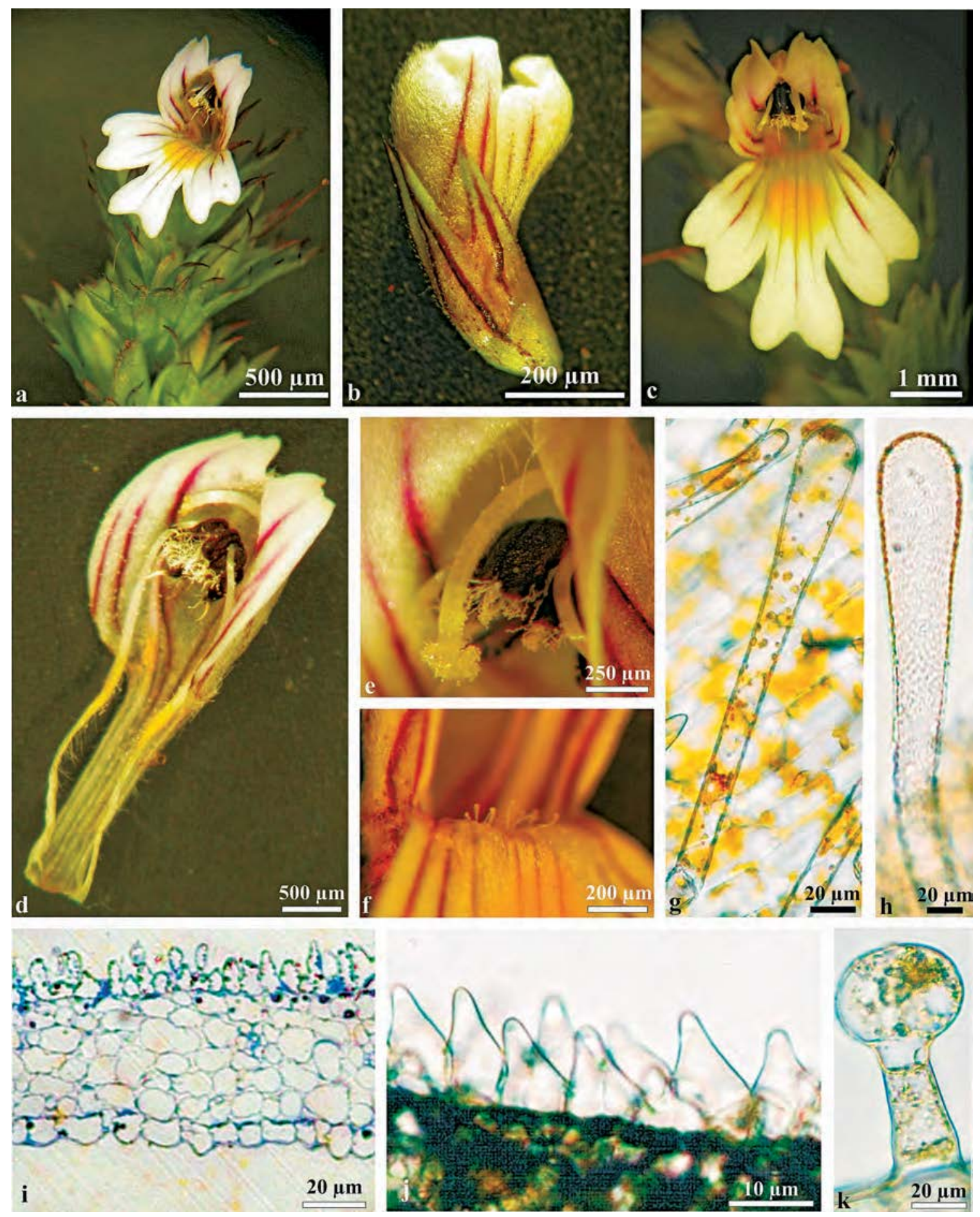

Fig. 1. Flowers of the drug eyebright, their fragments, and corolla trichomes (LM)

a - apex of a flowering shoot,

b - eyebright flower in a bud stage, visible calyx with dark purple stripes,

c - mature eyebright flower,

d - upper lip with numerous trichomes,

e - fragment of the upper lip, visible stripes with ribbon-like white trichomes and the stigma,

$\mathrm{f}$ - fragment of the lower lip with a yellow spot and clavate trichomes,

$\mathrm{g}$ - 3-celled clavate trichome, chromoplasts visible in the cells,

$\mathrm{h}$ - 1-celled clavate trichome,

i - cross-section of a fragment of a petal, visible papillae,

$\mathrm{j}$ - conical papillae on the adaxial surface of the lower lip,

$\mathrm{k}$ - capitate trichome with a 1-celled head and a 3-celled stalk. 

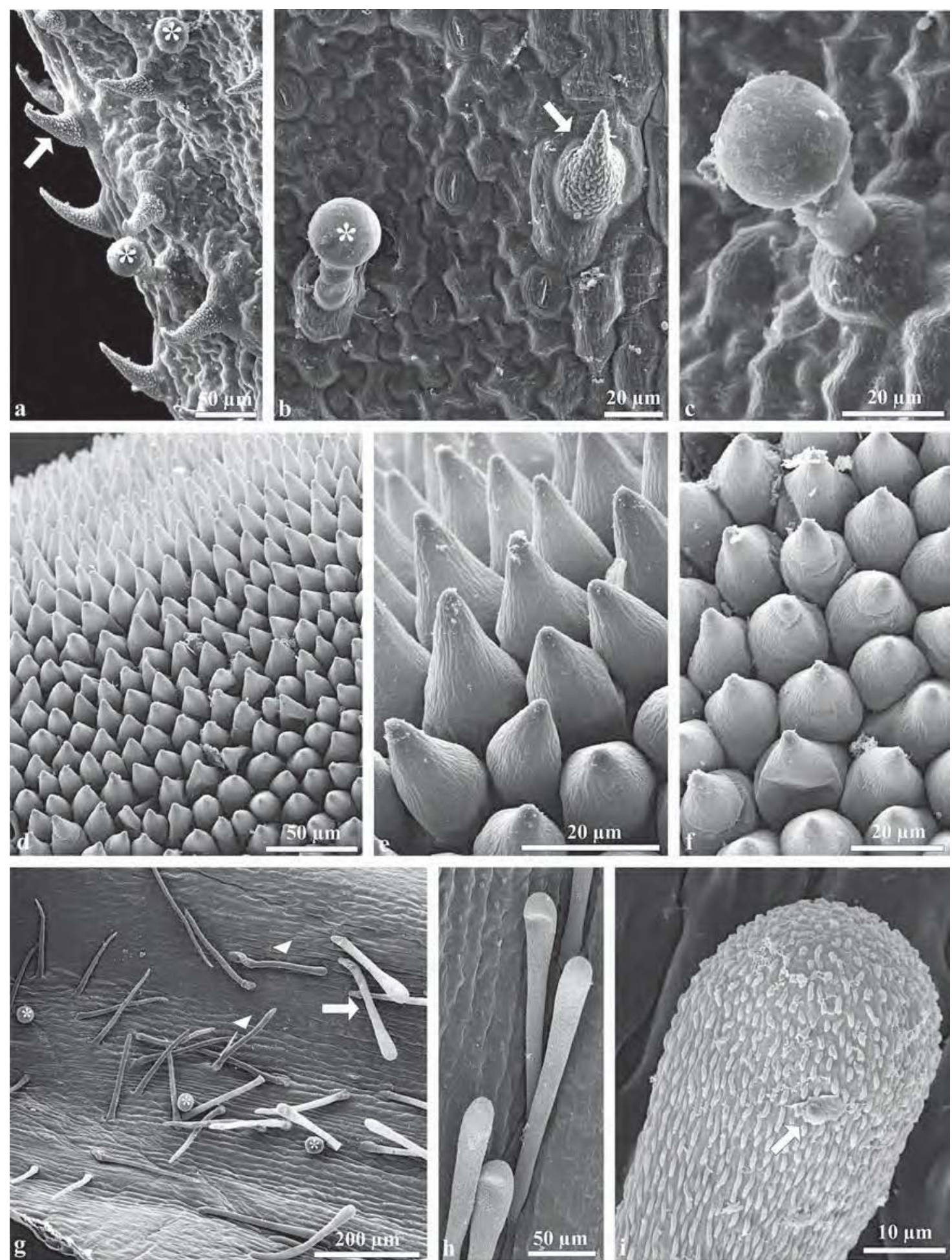

Fig. 2. Fragments of the calyx $(\mathrm{a}-\mathrm{c})$ and corolla $(\mathrm{d}-\mathrm{i})$ of the drug eyebright with various types of trichomes (SEM)

$a-b-$ calyx surface with hook-shaped mechanical trichomes (arrow) and capitate glandular trichomes (asterisks),

c - magnification of a capitate glandular trichome on the calyx surface,

d-f - lower lip covered by papillae, e - visible striae converging at the trichome apex, $\mathrm{f}-$ papillae with accumulated secretion in their apical part,

$\mathrm{g}$ - fragment of the lower lip, visible capitate (asterisks), clavate 2-3-celled (arrowheads), and clavate unicellular trichomes (arrow),

h - unicellular clavate trichomes,

i - magnification of the apical part of a unicellular clavate trichome, visible cuticular striae and secretion on the trichome surface (arrow). 

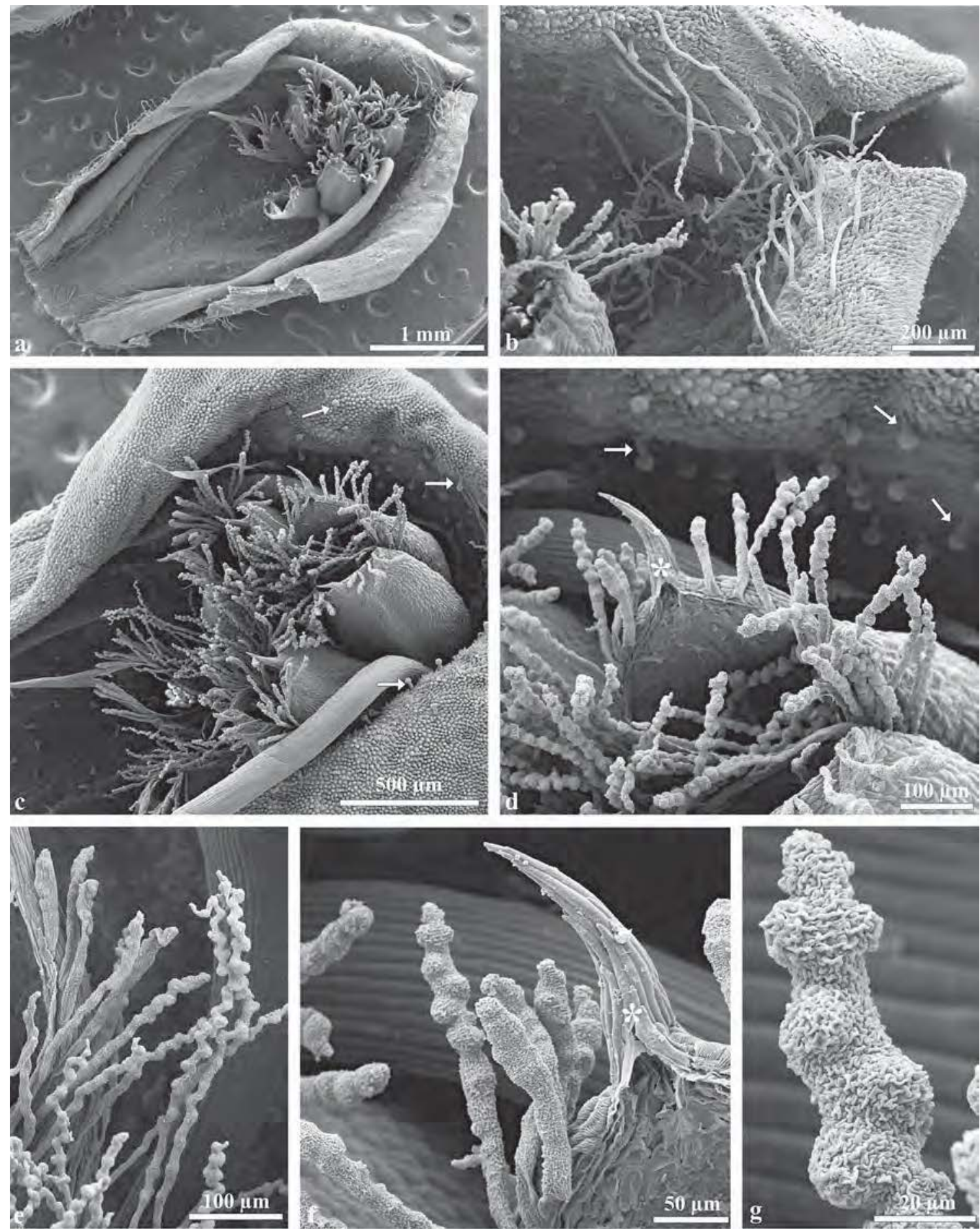

Fig. 3. Fragments of the upper lip with ribbon-like trichomes with thickenings (SEM)

a - general view of the upper lip, visible external long mechanical trichomes, ribbon-like trichomes in the upper part, and hairs on the anther surface,

$\mathrm{b}$ - magnification of the apical part of the upper lip with ribbon-like trichomes,

$\mathrm{c}$ - magnification of stamen heads with visible thickened ribbon-like trichomes on their surface, papillae covering the adaxial surface, and capitate glandular trichomes among them (arrows),

$\mathrm{d}$ - magnification of fragments of open stamen heads with a visible appendage (asterisk) and thickened ribbon-like trichomes and capitate trichomes (arrows),

e - thickened ribbon-like trichomes,

$\mathrm{f}$ - magnification of the apical part of the anther with an appendage (asterisk) and thickened ribbon-like trichomes,

$\mathrm{g}$ - apical part of a ribbon-like trichome, visible thickenings and an undulating surface covered by tightly arranged cuticular striae. 


\section{DISCUSSION}

The results of the microscopic analyses of $E u$ phrasia stricta trichomes revealed 10 different types of epidermal structures on the flower surface in this species (Table 1). It was also observed that the corolla trichomes were characterised by higher structural diversity than the sepal trichomes. Metcalfe and $\mathrm{Chalk}$ [20] have reported that abundant hairs with considerable diversity of forms can frequently be found in representatives of the family Scrophulariaceae.

In literature, there is scanty information concerning trichomes in plants from the family Scrophulariaceae, previously comprising the genus Euphrasia, or Orobanchaceae, to which the genus is classified currently [2,5]. Likewise in Calceolaria adscendens from the family Scrophulariaceae, Euphrasia stricta organs had glandular trichomes with a 2-celled head and a short stalk [21]. A paper describing the diversity of trichomes in plants growing in Pakistan provides examples of species from the genus Veronica (Scrophulariaceae), in which only 2 types of hairs, uniseriate and peltate, have been found [22].

Investigations of Orobanche pallidiflora indicated the presence of numerous glandular trichomes in the flowers of the plant, likewise in the eyebright. However, the trichome head in O.pallidiflora is not composed of 1 or 2 secretory cells as that observed in our Euphrasia preparations, but it consists of 9 to 14 cells arranged in a single concentric disk forming the trichome apex [23].

We observed accumulated secretion in the apical parts of the clavate trichomes and papillae in E. stricta. In many plants, essential oils produced in flowers are released via papillae and other types of trichomes $[24,25,26]$.

Eyebright extracts are widely used in treatment of ophthalmic diseases thanks to the presence of a variety of bioactive substances in plant tissues. The major compounds detected in plants from this genus include iridoid glycosides, tannins, phenolic acids, coumarin, resin compounds, and mineral salts [27,28,29]. Some of these secondary metabolites can be produced by external secretory structures such as glandular trichomes. Evert [30] reports that trichomes in plants from the family Scrophulariaceae are able to produce lipophilic substances, some of which have been extracted from eyebright herb. Ponzi and Pizzolongo [31] demonstrated that capitate trichomes present on the surface of leaves in another representative from the family Scrophulariaceae (Rhinanthus minor) may serve a function of active hydatodes, the so-called trichome-hydatodes, which secrete salt solutions and other compounds.

The ribbon-like trichomes with thickenings that we have found on the surface of the stamen heads and the upper lip of Euphrasia stricta flowers have not been yet reported in the literature concerning the family Scrophulariaceae. The structures located on the anthers are directed towards the entry to the flower throat and thus they probably show insects the access to pollen. They may also serve as pollen presenters, from which insects collect numerous pollen grains that remain on their surface when released from the anthers. Pollen presenters located at the pistil apex have been described in plants from many families (e.g. Asteraceae, Campanulaceae, Fabaceae, Rubiaceae, Proteaceae, Lobeliaceae) [32,33]. Trichomes on Euphrasia anthers may have the same role.

\section{Acknowledgements}

This research was supported by the Ministry of Science and Higher Education of Poland as a part of the activities of the Department of Botany, University of Life Sciences in Lublin.

\section{Authors' contribution}

Concept of study: EW-C; field research: WH; microscopical analysis: WH, EW-C; writing of manuscript: WH, EW-C; photographs: WH, EW-C.

\section{REFERENCES}

1. Szafer W, Kulczyński S, Pawłowski B. Rośliny polskie. PWN. Warszawa. 1986 (in Polish)

2. Mirek Z, Piękoś-Mirkowa H, Zając A, $\mathrm{Z}$ ając M. Flowering plants and pteridophytes of Poland: a checklist. Krytyczna lista roślin naczyniowych Polski. Instytut Botaniki PAN im. Władysława Szafera w Krakowie; 2002.

3. St a s zkiew ic z J. Euphrasia exaristata (Scrophulariaceae), a Western Carpathian endemic species new to the flora of Poland. Pol Bot J. 2009; 54(1): 27-29.

4. Posz (Proszkiewicz) E. Rozmieszczenie gatunków z rodzaju Euphrasia L. w polskiej części Tatr. Nauka a zarządzanie obszarem Tatr i ich otoczeniem. 2010; Vol. II: 17-21. (in Polish)

5. Stevens PF. Angiosperm Phylogeny. http//mobot.org/ Research/APWeb/welcome.html

6. Mizianty M. Problemy taksonomiczne w rodzaju Euphrasia L. Wiadomości Botaniczne. 1980; Vol. 24 (2): 153-162. (in Polish)

7. Kolseth AK, Lönn M, Svensson BM. Genetic structure in two meadow varieties of Euphrasia stricta on the Baltic island of Gotland (Sweden) and implications for conservation. Folia Geobot. 2005; 40: 163-176. http://dx.doi. org/10.1007/BF02803232.

8. Grandos L, Lane SD. A fine scale study of selected environmental and floristic parameters in three population of Euphrasia vigursii (Davey), a rare annual enemic to Devon and Cornwall. Watsonia. 2007; 26: 347-358. 
9. Posz (Proszkiewicz) E. Euphrasia minima Jacq. (Orobanchaceae) w Karkonoskim Parku Narodowym. Opera Corcontica. 2010; 47/2010 suppl.1: 153-158. (in Polish)

10. Ye o P. Germination, Seedlings, and the Formation of Haustoria in Euphrasia. Watsonia. 1961; 5: 11-22.

11. Svens son BM, Carls s on B $\AA$. Significance of time of attachment, host type, and neighbouring hemiparasites in determining fitness in two endangered grassland hemiparasites. Ann Bot Fennici. 2004; 41:63-75.

12. Rumińska A, Ożarowski A. (red). Leksykon roślin leczniczych. PWRiL. Warszawa. 1990. (in Polish)

13. Broda B, Mows zowicz J. Przewodnik do oznaczania roślin leczniczych, trujących i użytkowych. Wyd. Lekarskie PZWL. Warszawa. 1996. (in Polish)

14. Rawski M. Pożytki pszczele. Cz. III. Wartość pożytkowa roślin dzikich i uprawnych. Wyd. „Ex Libris”, Warszawa. 1948. (in Polish)

15. Gomez JM. Self - pollination in Euphrasia willkommii Freyn (Scrophulariaceae), an endemic species from alpine of Sierra Nevada (Spain). Plant Syst Evol. 2002; 232: 63-71. http://dx.doi.org/10.1007/s006060200027

16. Petrichenko VM, Sukhinina TV, Babiyan LK, Shramm NI. Chemical composition and antioxidant properties of biologically active compounds from Euphrasia brevipila. Pharmaceutical Chemi J. 2006; 40. No.6. 22-26. http://dx.doi.org/10.1007/s11094-006-0117-4

17. Shestakova TS, Petrichenko VM, Sukhin in a T V. Elemental composition of Euphrasia brevipila herbs and extracts. Pharmaceutical Chemi J. 2008; 42 (8): 460-462. http://dx.doi.org/10.1007/s11094-008-0149-z

18. Blazics B, Alberti Á, Béni S, Kurniszki L, Tölgyesi L, Kéry Á. Identifacation and LC-MS-MS Determination of Acteoside, the Main Antioxidant Compound of Euphasia rostkoviana, Using the Isolated Target Analyte as External Standard. J Chromatografic Sci. 2011; 49, 203-208. http://dx.doi.org/10.1093/chrsci/49.3.203.

19. Dimitrova M, Hristova L, Damianova E, Yordanova Y, Petrova N, Kapchina-Toteva V. Antioxidant activity and secondary metabolites in different extracts of Euphrasia officinalis L. growing in Bulgaria. Science\&Technologies. Medicine. 2013; III(1): 128-132.

20. Metcalfe CR, Chalk L. Anatomy of dicotyledons. Oxford at the Clarendon Press. 1972.

21. Sacchetti G, Romagnoli C, Nicoletti M, Di Fabio A, Bruni A, Poli F. Glandular trichomes of Calceolaria adscendens Lidl. (Scrophulariaceae): histochemistry, development and ultrastructure. Ann Bot. 1999; 83: 87-92. http://dx.doi.org/10.1006/anbo.1998.0778.

22. Khan G, Zhang F, Gao Q, Mashwani Z, Rehman K, Khan MA, Chen S. Trichomes diversity in the tropical flora of Pakistan. J Med Plants Res. 2013; 7(22): 1587-1592. http://dx.doi.org/10.5897/JMPR11.1336.

23. Konarska A, Chmielewski P, Sulborska A. Morphology and histochemistry of glandular trichomes of Orobanche pallidiflora Wimm. \& Grab. flowers. Materiały konferencyjne: 3rd International Conference and Workshop - Plant - the source of research material. 2013: 135.
24. Weryszko-Chmielewska E, Sulborska A.Diversity in teh structure of the petal epidermis emitting odorous compounds in Viola $x$ wittrockiana Gams. Acta Sci. Pol., Holtorum Cultus. 2012; 11(6): 155-167.

25. Sulborska A, Weryszko-Chmielewska E, Chwil M. Micromorphology of Rosa rugosa Thunb. petal epidermis secreting fragrant substances. Acta Agrobot. 2012; 65(4): 21-28. http://dx.doi.org/10.5586/aa.2012.018.

26. Schultze W, Zänglein A, Hose S, Kubeczka KH, Czygan FC. Volatiles in flowers of balm (Melissa officinalis L.). [In:] Advances in Labiate Science. Royal Botanic Garden, Kew. 1992: 357-366.

27. Hoj de m B. Świetlik łąkowy - ulga dla oczu. Wiad. Ziel. 2000; 42: 7-8. (in Polish)

28. Ersöz T, Berkman MZ, Tasdemir D, Calis I, I re la nd CM. Iridoid and phenylethanoid glycosides from Euphrasia pectinata. Turk. J Chem. 2002; 26: 179-188.

29. Matysik-Woźniak A, Matysik E, Weryszko-Chmielewska E, Paduch R. Wykorzystanie ziół w leczeniu zapalenia spojówek - wybrane aspekty. Zdr Publ. 2011; 121(1): 104-108. (in Polish)

30. Evert R F. Esau's Plant Anatomy. Meristems, cells, and tissues of the plant body: their structure, function and development. John Wiley \& Sons, Inc. Hoboken, New Jersey. 2006.

31. Ponzi R, Pizzolongo P. Structure and function of Rhinanthus minor L. trichome hydathode. Phytomorphol. 1992; 42: 1-6.

32. Howell GJ, Slater AT, Knox RB. Secondary pollen presentation in Angiosperms and its biological significance. Aust J Bot. 1993; 41: 417-438. http://dx.doi.org/10. 1071/BT9930417.

33. Mattews ML., Gardner J, Sedgley M. The proteaceous pistil: morphological and anatomical aspects of the pollen presenter and style of eight species across five genera. Ann Bot. 1999; 83: 385-399. http://dx.doi.org/10.1006/ anbo.1998.0837.

\section{Cechy strukturalne włosków w kwiatach świetlika wyprężonego (Euphrasia stricta D. Wolff ex J. F. Lehm.)}

\section{Streszczenie}

Euphrasia stricta D. Wolff ex J. F. Lehm. (Orobanchaceae) jest jedną z roślin szeroko stosowanych w medycynie ludowej, fitomedycynie i homeopatii. Surowiec leczniczy pochodzący ze świetlika wykorzystywany jest głównie w terapii schorzeń okulistycznych.

Badania włosków występujących w kwiatach świetlika wyprężonego (Euphrasia stricta D. Wolff ex J. F. Lehm) przeprowadzono w latach 2010-2011. Przy zastosowaniu mikroskopii świetlnej i skaningowej elektronowej określono lokalizację, cechy budowy morfologicznej i anatomicznej włosków. Stwierdzono 
obecność 3 typów włosków mechanicznych: krótkie jednokomórkowe, długie 1-2-komórkowe oraz długie 2-komórkowe z ornamentacją ściany. Ponadto zaobserwowano 7 rodzajów włosków gruczołowych: maczugowate jednokomórkowe, maczugowate 2-3-ko- mórkowe, główkowate z 1-komórkową główką i 3-komórkowym trzonkiem, główkowate z 1-komórkową główką i 2-komórkowym trzonkiem, główkowate z 2-komórkową główką, stożkowate papille oraz włoski taśmowate ze zgrubieniami ścian.

Handling Editor: Elżbieta Pogroszewska

This is an Open Access digital version of the article distributed under the terms of the Creative Commons Attribution 3.0 License (creativecommons.org/licenses/by/3.0/), which permits redistribution, commercial and non-commercial, provided that the article is properly cited.

CThe Author(s) 2013 Published by Polish Botanical Society 